Portland State University

PDXScholar

1971

\title{
Life history of Philophthalmus megalurus (Cort, 1914) in western Oregon
}

Toni Anne McMillan

Portland State University

Follow this and additional works at: https://pdxscholar.library.pdx.edu/open_access_etds

Part of the Bacteriology Commons, Environmental Microbiology and Microbial Ecology Commons, and the Pathogenic Microbiology Commons

Let us know how access to this document benefits you.

\section{Recommended Citation}

McMillan, Toni Anne, "Life history of Philophthalmus megalurus (Cort, 1914) in western Oregon" (1971). Dissertations and Theses. Paper 1432.

https://doi.org/10.15760/etd.1431

This Thesis is brought to you for free and open access. It has been accepted for inclusion in Dissertations and Theses by an authorized administrator of PDXScholar. Please contact us if we can make this document more accessible: pdxscholar@pdx.edu. 
AN ABSTRACT OF THE THES IS OF Toni Anne McMillan for the Master of Science in Biology presented May 27, 1971.

Title: Life History of Philophthalmus megalurus (Cort, 1914) in Western Oregon.

APPROVED BY MEMBERS OF THE THESIS COMMITTEE:

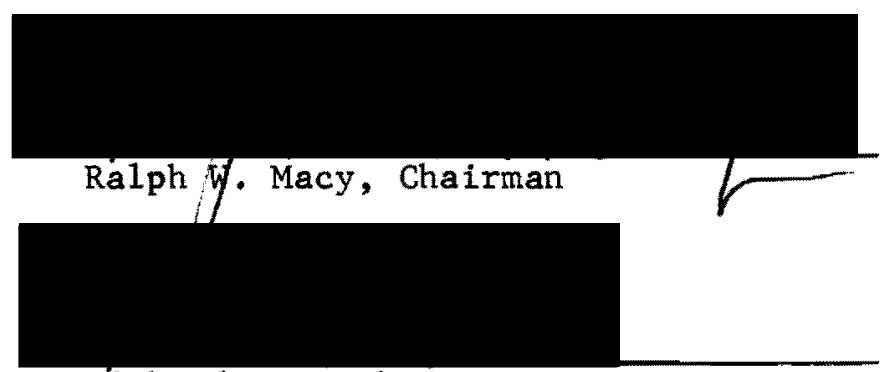

Richard B. Forbes

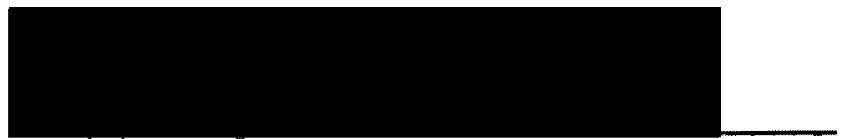

Robert 0 . Tinnin

Ths specific identification of a megalurous cercaria found in the snail Oxytrema plicifera was accomplished by completing the life cycle in the laboratory. This species is compared with the eastern Philophthalmus megalurus and $\underline{P}$. gralli with which it was once confused. The eggs, miracidia, and rediae of the Oregon species were found to be similar to those of the above species. The body and organ sizes and sucker ratios for the cercariae and adult stages obviously indicate that the Oregon species is Philophthalmus megalurus. 
LIFE HISTORY OF

PHILOPHTHALMUS MEGALURUS (CORT, 1914)

IN WESTERN OREGON

by

TONI ANNE MCMILLAN

A thesis submitted in partial fulfillment of the requirements for the degree of

\author{
MASTER OF SCIENCE \\ in \\ BIOLOGY
}

Portland State University

1971 
TO THE OFFICE OF GRADUATE STUDIES:

The members of the Committee approve the thesis of Toni Anne McMillan presented May 27, 1971.

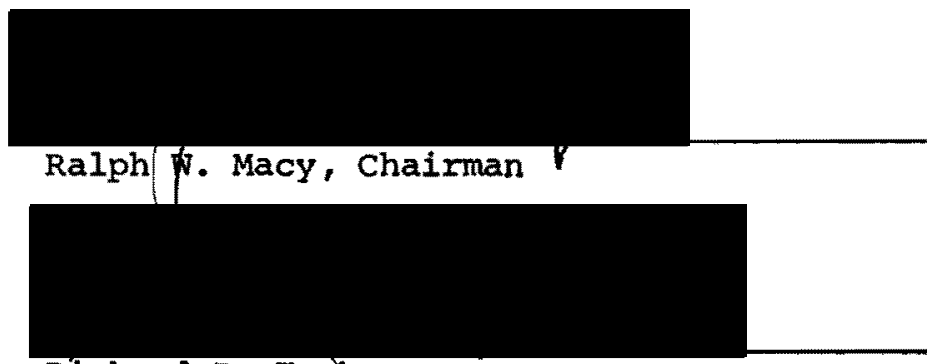

Richard B. Forbes

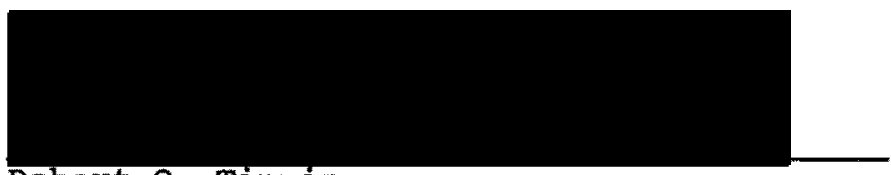

Robert 0. Tinnin

APPROVED :

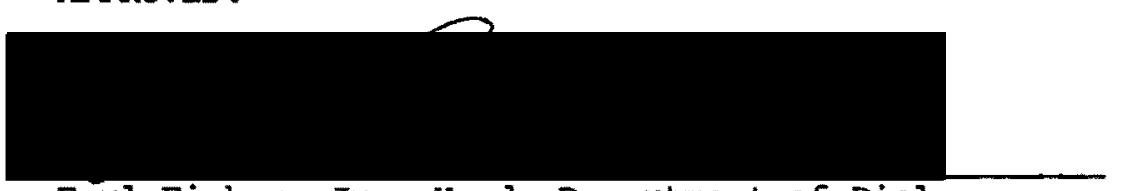

Earl Fisher, Jr., Head, Department of Biology

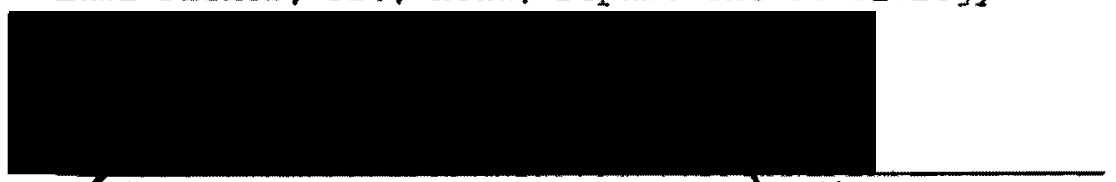

David T. Clark, Dean of Graduate Studies

May 27,1971 
TABLE OF CONTENTS

PAGE

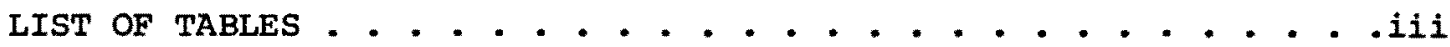
LIST OF FIGURES. . . . . . . . . . . . . . . . . . iv INTRODUCTION .......................... 1 METHODS AND MATERIALS. ..................... 3 TAXONOMY ............................ 5 RESULTS

Description of adult. . . . . . . . . . . 8 Egg and miracidium. . . . . . . . . . . . . . 13 Sporocyst and redia ................ 13

Cercaria and metacercaria . . . . . . . . . 16 DISCUSSION

Experimental methods. . . . . . . . . . . . . 19 Incidence and infection .............. 20 Species identification. . . . . . . . . . . . 23 CONCLUSIONS. . . . . . . . . . . . . . . . . . . 25 LITERATURE CITED . . . . . . . . . . . . . . . . 26 ADDITIONAL REFERENCES. . . . . . . . . . . . . . . 29 


\section{LIST OF TABLES}

TABLE

PAGE

I Size comparisons of Philophthalmus adults. . . . . . . II

II Size comparisons of Philophthalmus cercaria. . . . . . 17 


\section{LIST OF FIGURES}

FIGURES

PAGE

1

Adult Philophthalmus megalurus . . . . . . . . 12

2

Egg and miracidium ................ 14

3

Mother redia containing daughter rediae. . . . . . 14

4

Daughter redia containing developing cercariae . . . 14

5

Cercaria .................. . 14

6

Encysted metacercaria. . . . . . . . . . 14

7

Life cycle of philophthalmus megalurus . . . . . . 21 


\section{INTRODUCTION}

Fisher and West (1958) reported the genus Philophthalmus, an eye fluke of birds, as new to the United States when they found belted kingfishers (Megaceryle alcyon) and green herons (Butorides virescens) in Indiana infected with this parasite. West (1961) continued investigations on the biology of this trematode and discovered that the snails Goniobasis sp. and pleurocera acuta both harbored the larval stages. He identified the species as $\underline{P}$ gralli, a species first found in the Gulf of Tonkin by Mathis and Leger in 1910.

Alicata and Noda (1960) also described a philophthalmid found in Hawaiian coots as Philophthalmus gralli. Subsequent comparisons of the life cycles by Cable and Hayes (1963) taxonomically separated the two species. Mathis and Leger did not publish illustrations of p. gralli, but from their description Cable and Hayes concluded that the Indiana species was actually P. megalurus, the cercaria of which had been described by cort (1914) under the name Cercaria megalurus. On the basis of zoogeographical distribution as well as morphological grounds, the Hawaiian species was considered to be p. gralli.

Krygier and Macy (1969) found a dipper (Cinclus mexicanus) on the Nehalem River in Oregon infected with adult Philophthalmus megalurus. No larval stages were found at that time, but the intermediate host was anticipated to be oxytrema, a phylogenetic relative of Goniobasis and Pleurocera. This was the first report of the genus in the western United States.

Boyd and Fry (1971) recently found Philophthalmus megalurus in 
kingfishers in Massachusetts. It is now evident that this eye fluke is widely distributed across North America.

During the fall of 1970, large numbers of the snail Oxytrema

plicifera in northwest oregon were examined for larval trematodes. One snail harbored second generation redia with fully developed megalurous cercariae, thought to be of the genus Philophthalmus. Further confirmation of the species involved was sought by this investigator by comparing larval stages and adults grown in the laboratory with the reports of the known species $\underline{P_{.}}$gralli and $\underline{p_{.}}$megalurus. 
METHODS AND MATERIALS

Oxytrema were collected with a Needham rake and by hand from several locations on the Tualatin River. The Tillamook River, 80 miles west of the first locality, was also sampled. The incidence of infection on the Tualatin River was very low, 0.128 , while no infection was found for the Tillamook River. Only two of the 1645 snails were found to be infected with identifiable stages when isolated for shedding. For the purpose, five snails per plastic petri dish containing water, were placed in an environmental chamber at $14 \mathrm{C}^{\circ}$. They were allowed to shed cercariae for approximately three days. When no shedding occurred the snails were cracked to locate any immature stages. Besides the one snail found to contain second generation rediae, one other snail shed up to 135 cercariae, which encysted on the bottom of the dish. This snail shed for two days before death. Upon autopsy it was found to contain hundreds of second generation rediae with almost mature cercariae.

The encysted metacercariae were then scraped off the dish, often excysted in the process, and were then swirled toward the center for collection. These metacercariae, infective immediately upon excystation, were pipetted into the back of the mouths of two 2-3 day old chickens (Gallus gallus domesticus).

Maturation was allowed to continue for 29 days in one chick and 72 days in the other. The chickens were then sacrificed to collect the adults, although West (1961) states that it is possible to collect the adults with a pipette without harm to the avian host. 
The adults were put in $0.45 \% \mathrm{NaCl}$ in which eggs were laid. The eggs hatched almost immediately, releasing miracidia, which had prominent eyespots. Measurements of the miracidia were taken when alive. In order to expose them to miracidia, Oxytrema snails were isolated in small stender dishes containing aquarium water. The snails were returned to the tanks in about 15 minutes when no more miracidia were visible in the dishes indicating completed penetration.

At regular intervals the snails were sacrificed to examine for intermediate larval stages. All known stages of the parasite were examined alive and also most as fixed whole mounts. Two adults and half the rediae were stained with Semichon's carmine after fixation in A. F. A. to minimize discrepancies in measuring due to differences in fixation technique used by west (1961) and myself. The other adults and rediae were fixed in Gilson's fluid and stained with more permanent Erlich's acid hematoxylin. Cercariae were fixed in hot A. F. A. and hot 108 formalin and measured as temporary whole mounts.

Measurements are in millimeters with the mean of each followed by the range in parentheses. Illustrations were made with the aid of a camera lucida. 
In 1939 Gower prepared a key for genera of Philophthalmidae. Baugh (1962) redescribed the family and gave a key to the subfamilies Philophthalminae and cloacitreminae. The family contains mainly eye flukes, with some intestinal and cloacal members.

The comprehensive taxonomic review of Philophthalmus by West (1961) was followed by further elucidation of the position of P. gralli Mathis \& Leger, 1910, by Cable and Hayes (1963), who split that species into the Pacific fluke p. gralli and the North American freshwater fluke P. megalurus.

Since 1963 at least eleven new species have been added to the family Philophthalmidae. Philophthalmus hegeneri Penner \& Fried, 1963, is found in the eyes of many marine birds in Florida. This is the only new North American species.

The Russian scientist Belapolskaya (1963) reported Philophthalmus enterobius from the intestine of a curlew Numenius madagascariensis which differs from P. skrjabini Efimov, 1937, in the relative size of suckers, rounded testes, and length of cirrus sac. He also located Ophthalmus grandis in the same bird. O. grandis is larger than 0 . numenii Sobolev, 1943, and lacks an esophagus, has lobed testes, and the uterine loops extend to the lateral sides of the body.

Oshmarin (1963) announced finding Philophthalmus (Tubolecithalmus) proboscidus in ducks and P. (T.) macrorchis, which is found in the rail, in Russia. The three subgenera include the Tubolecithalmus which has tubular vitellaria and the Philophthalmus which has follicular 
vitellaria; the third, Mixophthalmus, is a combination of the other two with the anterior vitellaria follicle-like and the posterior vitellaria resembling tubules. Mixophthalmus was established by Karyakarte (1967a) in India, when he found the yellow-eyed babbler Chrysomna sinensis infected with an eye fluke which he termed $\underline{P}_{.}\left(M_{-}\right)$chrysomae. Karyakarte $(1967 \mathrm{~b}, 1968)$ also located two other eye flukes, one in the orbit of vultures Neophron percnopterus and the other in pigeons Columbia livia Gmelin. Specific names were not given at that time, however.

The coot Fulica atra from the Ukraine was recently found by Iskova to be infected with Philophthalmus stugii (1967).

In 1965 Vasilev and Denev recovered a species of Philophthalmus from the eyes of geese in Bulgaria. Life history studies indicate great similarities to $\underline{P}$. gralli in Hawail as described by Alicata and Noda in 1960. Further research on these similarities and those of nearby states should be published shortly by the Bulgarian parasitologists.

Murty (1966) demonstrated the life cycle of an unknown species of Philophthalmus found in India. The megalurous cercariae were collected from $30 \%$ of the snails Melanoides tuberculatus examined.

This author agrees with West (1961) and Ching (1961) that work needs to be devoted to reducing to synonymy some species of the genus. This "splitting" has evolved through species discrimination based on minute differences in size and shape of organs, discrepancies often found within a species as West (1961) found in Philophthalmus megalurus. Discovery of flukes in new hosts and areas often prompts the birth of 
a new species. Unless these differences are substantiated by life cycle studies they should be considered only as individual variations within the species and taxonomically insignificant. 


\section{RESULTS}

DESCRIPTION OF ADULT PHILOPHTHALMUS IN WESTERN OREGON (FIgure 1.)

This description is based on four specimens obtained from experimentally infected chicks, measured as stained whole mounts.

The adults are elongate with the hind body somewhat expanded when flattened. The mature specimens are $5.15(4.8-6.0)$ long and 1.7 (1.5-2.0) wide. The terminal oral sucker is $0.35(0.28-0.37)$ by 0.39 (0.30-0.47), with the mouth slightly subterminal. The very short prepharynx mentioned by west (1961) is not evident. The pharymx is somewhat smaller than the oral sucker, $0.31(0.29-0.33)$ by 0.32 (0.27-0.37). The esophagus bifurcates one fourth the distance between the pharymx and ventral sucker, with the ceca continuing to the posterior end of the body with few shallow sinuses. The ventral sucker in the anterior one fourth of the body is $0.58(0.48-0.67)$ in diameter.

The tandem testes are entire to slightly lobed. The anterior testis is $0.45(0.37-0.60)$ long and $0.68(0.63-0.74)$ wide; the posterior testis measures $0.49(0.38-0.59)$ long and $0.60(0.48-0.83)$ wide. Dorsal or lateral to the ventral sucker is the cirrus sac $1.37(1.30-1.51)$ long by $0.18(0.13-0.21)$ wide, which always overreaches that sucker. The cirrus is very large upon eversion. The genital openings are separate, opening into a shallow atrium immediately beneath the cecal bifurcation. In the posterior one third of the body, anterior to the testes, 1ies the rounded ovary $0.27(0.22-0.32)$ in diameter. A tail-1ike extension of the ovary joins the narrow oviduct which then enlarges to form a fertilization chamber. Next, Laurer's canal joins the oviduct, followed 
by the duct from the vitelline reservoir. From the vitelline reservoir two ducts extend laterally to the extracecal vitellaria which are tubular to follicular in shape. The vitellaria lie between the ventral sucker and the anterior testis. The Mehlis gland, ootype and proximal part of the uterus all are posterior to the ovary. The uterine coils sometimes extend posterior and lateral to the anterior testis. They occupy most of the mid-body posterior to the ventral sucker, with the metraterm paralleling the cirrus sac at the distal end of the uterus. The developed eggs in the uterus contain oculated miracidia which each contain a developed sporocyst.

Excretory trunks originate on each side of the pharynx and descend intracecally to the posterior end joining to form a triangular to $\mathrm{T}-$ shaped excretory vesicle. This vesicle empties through the terminal excretory pore.

Table I indicates the similarity of body and organ size between the Oregon species and Philophthalmus megalurus. The size ranges for $\underline{P}$. megalurus are greater, probably due to the larger number of specimens collected, and the variety of hosts from which the worms came. The ages of the worms were also variable, having come from wild, naturally infected birds at various times (West, 1961). West (1961) states that the data for the experimentally raised worms were more uniform when fed a single lot of metacercariae, a situation which also applies to the present study.

Philophthalmus gralli adults are quite small compared to the local species and $\underline{P}$. megalurus. There is some overlap of organ sizes, always in the minimal size range, however. It is significant to note that the 
ratio of suckers in $\mathrm{P}_{\text {. megalurus }}$ and the oregon species are very similar, $1: 1.8$ and $1: 1.6$ respectively. The sucker ratio for $\underline{\mathrm{p}}$ gralli is much smaller, $1: 1.1$.

Only chickens (Gallus gallus domesticus) were experimentally infected.

No natural definitive hosts were collected for this study. Kingfishers (Megaceryle alcyon) and dippers (Cinclus mexicanus) have been reported for this fluke. Great blue herons (Ardea herodias) and mallards (Anas platyrhynchos) are closely related to other previously recorded hosts. All of these water birds have been seen in the vicinity and might harbor the adult worm.

Other localities and natural hosts include: ducks (Anas boschas domestica) in Formosa, chickens (Gallus gallus domesticus) in Indo-China, ducks (Nyroca ferina) in Japan, and green herons (Butorides virescens), American bitterns (Botaurus lentiginosus), and grackles (Quiscalus quiscula) in Indiana.

The actual site of infection in the definitive host is the orbit of the eye. The preferred location is under the nictitating membrane near the lacrimal duct outlet.

In the experimental chicken of 29 days, which contained a single worm in each eye, there were no visible signs of infected tissue. In the 72 day old chick two worms were found in the bird's left eye, and considerable inflammation was evident. The eye was reddened and the lacrimal tissue was thickened in response to the presence of the worms. Penner and Fried (1963) also noted serious damage in the chachalacas (Ortalis vetula) and Western gulls (Larus occidentalis) that were heavily infected with the marine fluke Philophthalmus hegeneri. 
TABLE I.

SIZE COMPARISON OF PHILOPHTHALMUS ADULTS

\begin{tabular}{|c|c|c|c|}
\hline & Oregon species ${ }^{1}$ & P. meqalurus ${ }^{2}$ & P. $\operatorname{aral1} i^{3}$ \\
\hline Body length & $4.8-6.0$ & $3.82-8.36$ & $2.46-3.41$ \\
\hline Body width & $1.53-2.0$ & $0.67-2.07$ & $0.59-1.13$ \\
\hline oral sucker & $0.28-0.37 \times 0.30-0.47$ & $0.20-0.37 \times 0.21-0.47$ & $0.26-0.29 \times 0.29-0.37$ \\
\hline Ventral sucker (diam.) & $0.48-0.67$ & $0.43-0.70$ & $0.29-0.35$ \\
\hline Pharynx & $0.29-0.33 \times 0.27-0.37$ & $0.19-0.35 \times 0.17-0.31$ & $0.23-0.26 \times 0.20-0.26$ \\
\hline $\begin{array}{l}\text { Testes } \\
\text { anterior }\end{array}$ & $0.37-0.60 \times 0.63-0.74$ & $0.27-1.20 \times 0.25-0.87$ & $0.30-0.40 \times 0.36-0.56$ \\
\hline posterior & $0.38-0.59 \times 0.48-0.83$ & $0.25-1.01 \times 0.21-0.89$ & $0.26-0.40 \times 0.33-0.53$ \\
\hline Cirrus sac & $1.18-1.51 \times 0.13-0.21$ & $0.83-1.70 \times 0.09-0.32$ & $-m$ \\
\hline Ovary & $0.22-0.32 \times 0.28-0.30$ & $0.12-0.37$ diam. & $0.18-0.20$ diam. \\
\hline
\end{tabular}

1. Current work: Based on 4 adults taken from experimentally infected domestic chicks.

2. West, 1961: Based on numerous adults from wild, naturally infected birds and domestic chicks experimentally infected.

3. Alicata \& Noda, 1960: Based on 7 adults taken from experimentally infected domestic chicks. 
Figure 1. Adult Philophthalmus megalurus taken from under nictitating membrane of experimentally infected chicken.

Abbreviations: CI-cirrus; CS-cirrus sac; ET-excretory trunk; EVexcretory vesicle; GP-genital pore; ME-metraterm; OV-ovary; SR-seminal receptacle; SV-seminal vesicle; TE-testis; UT-uterus; VD-vas deferens; VE-vas efferens; VI-vitellaria. 


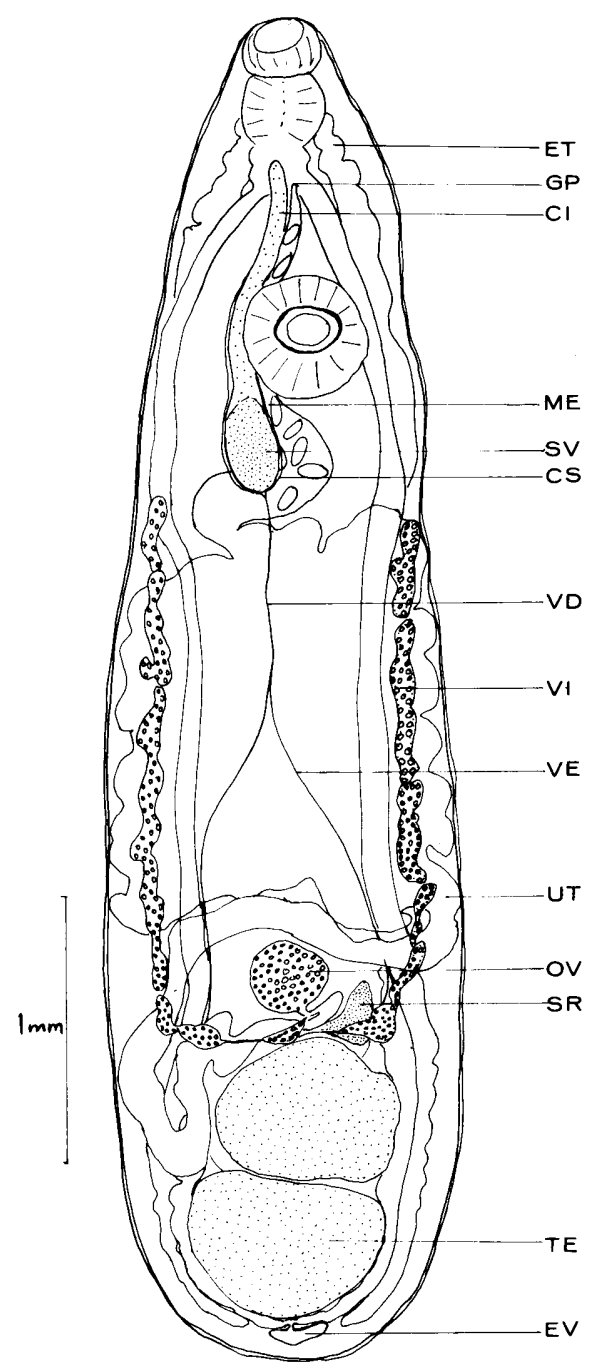


EGG AND MIRACIDIUM (Figure 2)

The philophthalmid eggs are oval and yellowish in color, reaching a size of 0.12 long by 0.07 wide when laid in $0.7 \% \mathrm{NaCl}$. One end of the egg is slightly larger and one side is flattened. The activity of the miracidium within the egg increases when the egg is released from the uterus, exerting pressure on the interior of the shell. This pressure forces the shell to rupture in a horizontal plane approximately one fourth of the distance from the enlarged end, allowing the miracidium to escape. Although no operculum is visible before hatching the egg shell always seems to break at the same place each time with the cap remaining hinged to the rest of the shell as if operculate.

When the mature adult, gravid with eggs, is placed in distilled water the eggs often hatch within the uterus. Eventually, the miracidia find their way through the uterus to the outside. The miracidium expands upon hatching to a size of 0.17 long and 0.07 wide. After several minutes of swimming in the vicinity of a snail the miracidium penetrates the epidermis of the foot or antennae.

The three philophthalmid eggs are very similar in size. The Oregon species measures 0.12 by 0.06 , Philophthalmus megalurus 0.11 by 0.05 , and P. gralli 0.15 by 0.06 . The miracidia are also comparable; the local species 0.16 by $0.07, \underline{p}$ megalurus 0.10 by 0.05 , and $\underline{p}$ gralli 0.12 by 0.06

SPOROCYST AND REDIA

The sporocyst stage is short-lived (20 days); Khalil and Cable only recently (1968) discovered this fact in their study of the germinal development of Philophthalmus megalurus. However, in the present study 
Figure 2-6. Intermediate stages of Philophthalmus megalurus. 2. Empty egg shell and miracidium. 3. Mother redia with developing daughter rediae. 4. Daughter redia containing developed cercariae. 5. Megalurous cercaria with adhesive glands in invaginated tail. 6. Encysted metacercaria.

Abbreviations: C-cercaria; EV-excretory vesicle; G-gut; LA-lateral appendages; PA-posterior appendage; PH-pharynx; TI-tail invagination. 


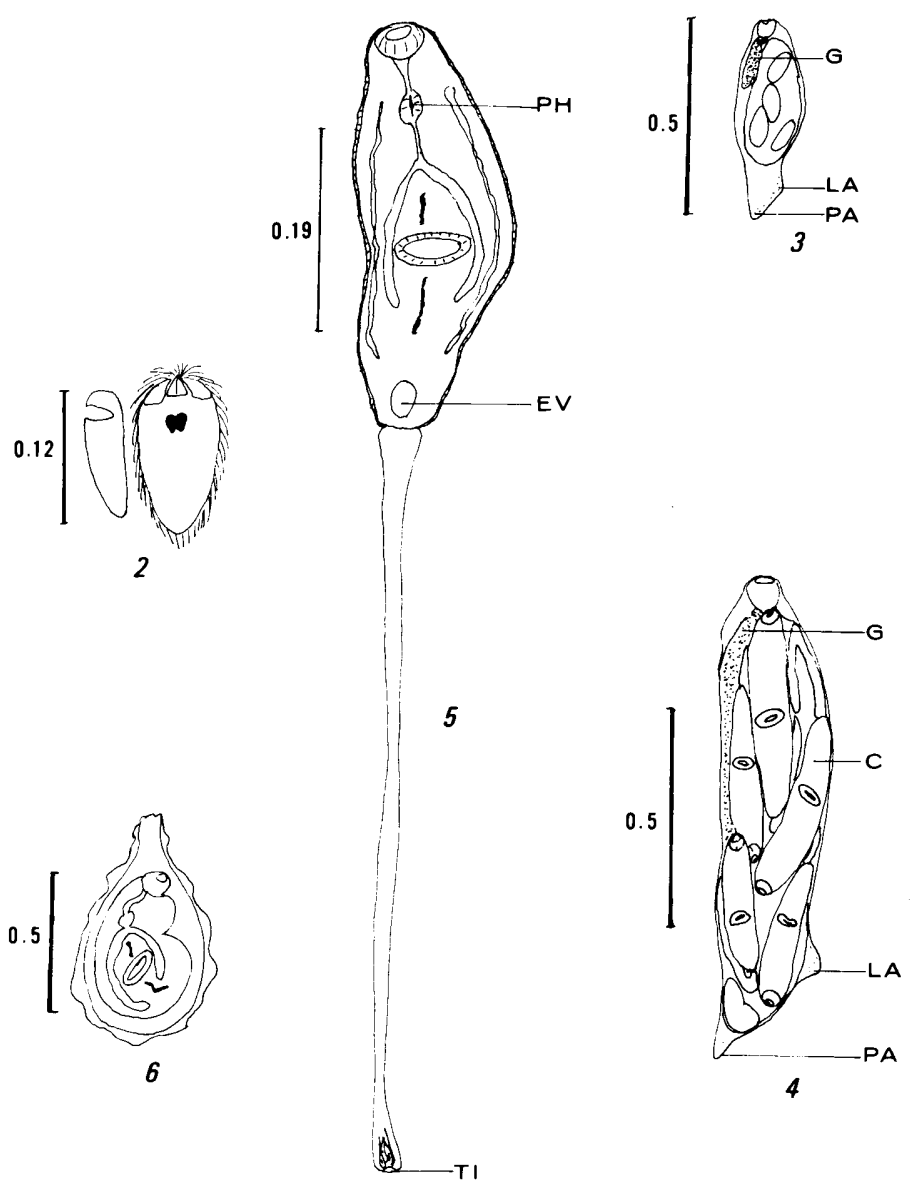


snails were not examined sufficiently early to find a sporocyst.

First and second generation rediae were present in the snail heart at 67 days post-infection when an Oxytrema was sacrificed for examination. Three to six daughter rediae were in each mother redia. Living mother rediae measured $0.41(0.32-0.48)$ long by $0.19(0.17-0.21)$ wide, while fixed specimens measured only 0.34 long by 0.11 wide (Figure 3). These mother rediae were very firmly attached to the host's cardiac tissue by their posterior and lateral appendages and were quite difficult to remove; thus a paucity of quantitative data concerning this stage. The figures given above therefore may not be truly representative of the first redial stage.

Daughter rediae were located also, but were not well developed at this time. Unflattened specimens measured only $0.24(0.14-0.30)$ long by $0.05(0.04-0.06)$ wide.

Upon examination of a second experimentally infected snail at three months (90 days), hundreds of mature daughter rediae, each containing from 2-9 megalurous cercariae, were found in the digestive gland of the snail. These advanced rediae averaged $1.02(0.68-1.59)$ long and 0.25 (0.15-0.46) wide (Figure 4). The birth pore is situated just below the oral sucker, but it is not often visible.

Many small undeveloped rediae were also present. Perhaps some daughter rediae were producing granddaughter rediae, although no evidence of second generation rediae containing these was found.

The lateral appendages on the daughter redia seem more distant from the posterior appendage than in the mother redia. The larger, more rounded shape of the mother redia, is also obvious. 
No size comparisons of these stages with related species were attempted. Confusion in identification of these developmental stages and the different times of measuring have made this impossible.

CERCARIA AND METACERCARIA

Diagnosis (measurements of newly emerged larvae killed in hot A. F. A. fixative or hot formalin.) This larval stage is obviously a member of the megalura group of cercariae. The body length measures $0.55(0.47-0.79)$ long and $0.12(0.11-0.12)$ wide, just anterior to the ventral sucker. A distinct indentation occurs at the level of the ventral sucker with the hind body somewhat narrower. Sensory papillae cover the body surface (Figure 5 ).

The prominent tail is $0.63(0.47-0.89)$ long and $0.02(0.01-0.02)$ wide. The enlarged tip is invaginated 0.01 , forming a cup-like adhesive organ served by several adhesive glands.

The suckers are similar in size. The oral sucker is $0.0510 .05-$ $0.06)$ by $0.04(0.03-0.06)$, while the ventral sucker is circular with a diameter of $0.06(0.05-0.07)$. The prepharynx extends 0.06 to the small pharynx, 0.03 long by 0.02 wide. The esophagus is $0.06(0.03-0.09)$ long, bifurcating midway to the ventral sucker.

Table II compares the sizes of Philophthalmus megalurus and P. gralli with the data obtained for this local species. Notable is the similarity of the local species to p. megalurus. The range of sizes for P. gralli is usually more limited than the remaining two or is smaller in size.

Upon being shed by the intermediate host snail, oxytrema plicifera, the cercaria moves about actively in the water, but often attaches to 
TABLE II.

SIZE COMPARISON OF PHILOPHTHAIMUS CERCARIA

\begin{tabular}{llll} 
& Oregon species & P. megalurus & P. gralli \\
\hline Body length & $0.47-0.79$ & $0.54-0.67$ & $0.54-0.57$ \\
Body width & 0.11 & $0.12-0.13$ & $0.04-0.05$ \\
Tail & $0.47-0.89 \times 0.01$ & $0.93-1.14 \times 0.04-0.05$ & $0.41-0.46 \times 0.04$ \\
Oral sucker & $0.05-0.06 \times 0.03-0.06$ & $0.06 \times 0.04$ & 0.06 diam. \\
Pharynx & $0.03 \times 0.02$ & $0.03-0.04 \times 0.01-0.02$ & -1 \\
Esophagus length & $0.03-0.09$ & $0.10-0.11$ & --1 \\
Ventral sucker (diam.) & $0.05-0.07$ & $0.06-0.07$ & 0.06
\end{tabular}


the substrate with its ventral sucker. The tail is not much help in swimming, but it does adhere to vegetation or a hard surface, waving the body vertically in the water.

If undisturbed, the cercaria settles to the bottom of the dish or stream to encyst, fastening itself to the smooth surface with its ventral sucker. Within 10-15 minutes, a pear-shaped cyst has formed and the larva has oriented its anterior end toward the narrow neck of the cyst (Figure 6 ). The cyst measures 0.58 long and 0.29 wide. The cercarial tail may remain attached to the cyst for some time after encystment.

Excystment occurred if the cyst was touched, releasing the metacercaria which is infective immediately after the encystment. The temperature of the avian host's body effects the excystment (Cheng \& Thakur, 1967), instead of the usual enzymatic or acidic properties of the host environment. 


\section{DISCUSSION}

EXPERIMENTAI METHODS

If further research is carried out with this fluke several modifications in the procedure would facilitate matters. In order to obtain a higher rate of infection in the definitive host, it would be best to infect the chicks through the median slit as Fried and Penner (1963) did. The method of pipetting metacercariae into the back of the bird's mouth, as was done in this study, is not as effective. of the many metacercariae put into the mouth of each bird, only two succeeded in reaching the eye, the natural site of infection.

Also in collecting the cysts, the metacercariae are often excysted. It is thought that the cyst provides additional protection to the metacercaria (Fried \& Penner, 1963), thus, an attempt should be made to retain it. Vasilev and Denev (1965) used 0.5-1 $\mathrm{mm}$ of 28 agar in the bottom of the petri dish in which the cercariae were shed. This enabled collection of the cysts without excysting them. These could then be used to infect the hosts orally.

It is possible to keep the experimental host alive, yet remove the fluke from the host's eye for observation. West (1961) indicated that it is possible to collect the adult worm with a pipette without harm to the avian host, but he did not mention his method of quieting the bird to enable this removal. Fried and Berry (1961) used Equi-Thesin from Jensen-Salsbery Labs, Inc. of Kansas City, Missouri, as an anesthetic for in vivo transplants of schistosomes and philopthalmids in birds. 
A local veterinarian gave me a compound which he had used recently with great success. The compound, Ketaject (ketamine hydrochloride), is dispensed on prescription and produced by Bristol Laboratories of Syracuse, New York. Unfortunately, neither the prescribed intraveneous or intramuscular dosages successfully anesthetized the four week old chick. As a result, chloroform was used and the chick sacrificed. Chloroform was also used on the 72 day old bird. Chloroform is irritating to the eye tissue and to the worm, which retreats into the lacrimal duct. The researcher must then gently ease it from its hiding place. The adult worm shows the same whitish transluscence as the nictitating membrane and, thus, is very difficult to locate. When the worm moves the uterus contracts, shifting the contained eggs. The eggs with their oculate miracidia show up as dark moving spots which attract the investigator's eye.

INCIDENCE AND INFECTION

The low incidence of intermediate host infection in the Tualatin River suggests that perhaps a transient bird carrying the adult philophthalmid stopped only temporarily at the river to feed. Another possibility is that an infected bird in the area is feeding on the periphery of its territory, but only rarely. A permanent resident would visit the river often, constantly infecting the oxytrema through repeated feeding by dipping its head in the water, thus, rinsing fluke eggs from its eyes (Alicata \& Noda, 1960) (Figure 7).

Feeding habits of the probable hosts, such as the kingfisher and dipper, also give a clue to modes of infection. Free, mature cercariae or accidentally excysted metacercariae in the river would be able to 
Figure 7. Life cycle of the trematode Philophthalmus megalurus found in eyes of water birds. 


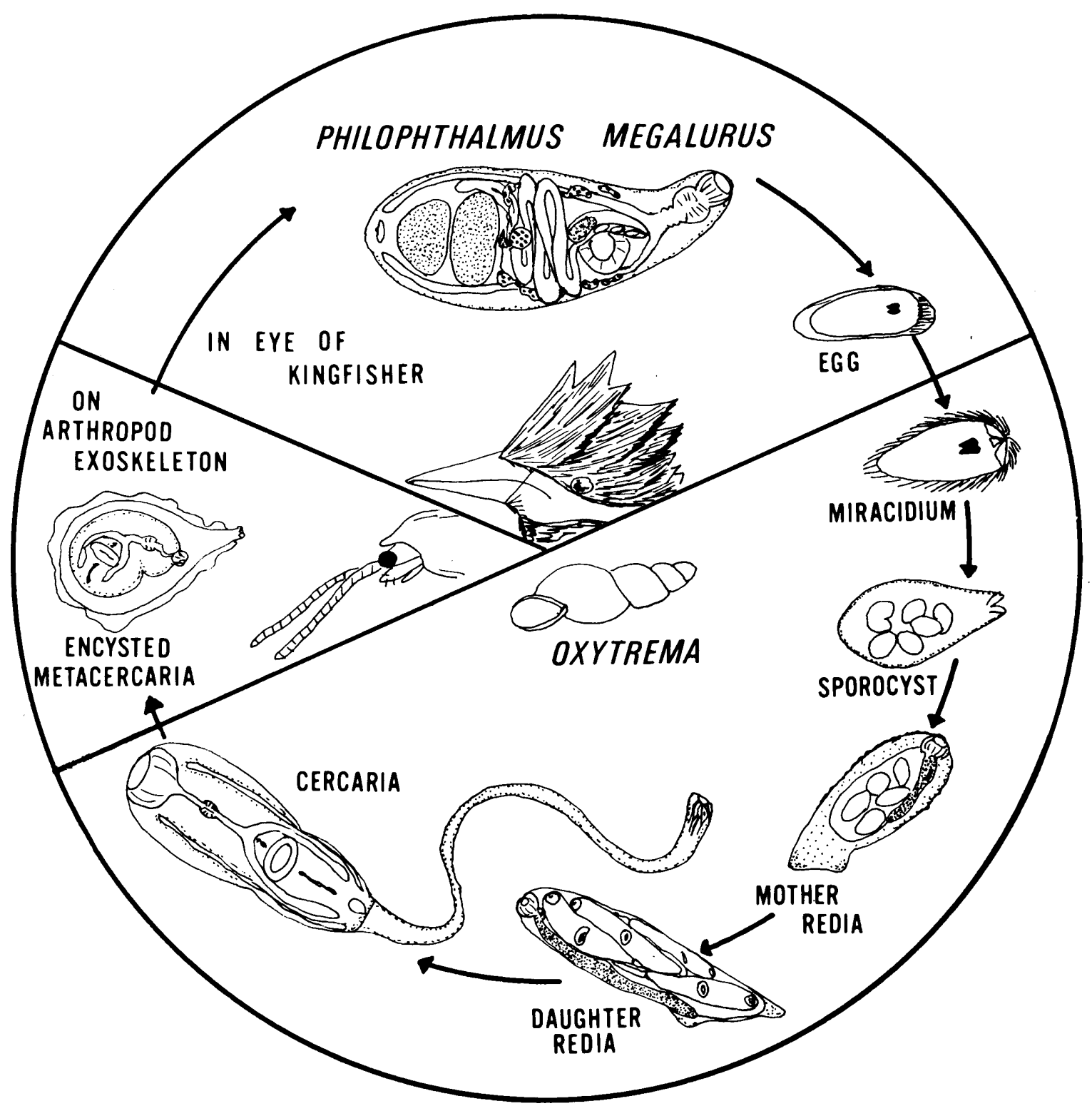


infect the birds orally, ocularly or through the median slit when the birds dip for fish or insects (Alicata \& Ching, 1960). West and Fisher (1959) suggested that cercariae normally encyst on a smooth surface such as an arthropod exoskeleton, since they readily encyst on petri dishes. Snail shells and fish scales might also be like surfaces, the Iatter most attractive to a fishing heron.

Harboring one or more worms does not protect the host against further or repeated infections. Fried (1963) tested chicks for possible immunization set up by the first Philophthalmus hegeneri adults and found that concurrent infections of different aged worms can occur. Cable (1937) reported a similar situation in a cloacal member of the same family, Parorchis acanthus. Certain birds, however, regardless of age were initially more resistant to infection than others, with no change in degree of susceptibility with repeated invasions.

Vertebrates other than birds may also become infected with these philophthalmids. Alicata and Ching (1960) and Alicata (1962) demonstrated that rats and rabbits may be infected ocularly with Philophthalmus gralli cercariae or metacercariae. The usual experimental chick host can be infected by these stages orally as well as by the ocular route.

Dissanaike and Bilimoria (1958) in Ceylon, reported a human infection of Philophthalmus, probably contracted while the host was vacation bathing in a South India river. The species was similar to P. lacrymosus Braun found by Markovic and Garxicic in Belgrade in 1939. This potential spread of human infection concerned Howell (1965) in New zealand, when he found 48 of the snails zeacumantus subcarinatus infected with philophthalmid cercariae in the Wellington area. There 
seems to be little probability of human infection on the Tualatin River, however, since the incidence is so low.

SPECIES IDENTIFICATION

No significant differences occur in the early developmental stages of the three Philophthalmus to separate them taxonomically. Neither West (1961) nor Alicata and Noda (1960) realized that the first intramolluscan stage they had recovered was a sporocyst instead of a mother redia. Why this was not evident, since the stage had no pharynx or gut, is uncertain. The external characteristics, which are very similar to the redia, must have been so misleading that they overlooked the internal differences.

Comparisons of the two or three redial stages cannot be made, if indeed granddaughter rediae are produced. No two workers have raised their experimental snails under the same conditions, thus affecting the development times required by the rediae. They have then collected their redial stages at times which were quite different from one another. Quantitative data cannot be correlated as a result.

However, the data in Tables I and II, for the adult and cercaria, indicates that the Oregon species is almost identical to Philophthalmus megalurus as described in Indiana. P. gralli cannot be considered a synonym for the Oregon species because of its small size. Even the important ratio of sucker sizes is significantly smaller, $1: 1.1$. The sucker ratio for $\underline{P}$. megalurus is $1: 1.8$, very similar to the local species $1: 1.6$.

By coupling this quantitative data with the descriptive data for the various stages, this author has determined that the local oregon 
philophthalmid is also Philophthalmus megalurus.

This identification also substantiates Krygier and Macy's (1969)

belief that oxytrema is the intermediate host for Philophthalmus

megalurus. 


\section{CONCLUSIONS}

All evidence concerning the Oregon trematode indicates that it is Philophthalmus megalurus, the same species described in Indiana. P. gralli, a closely related species found in Hawaii and Indo-china, is much smaller.

Although no definitive avian hosts were collected in this study, previously reported hosts and related species occur in the area. Many other water birds frequent the river during migration and might serve as a source of infection, as well as acting as reservoir hosts.

The intermediate host is Oxytrema, confirming previous assumptions that it might be the snail involved in the cycle.

Many studies remain concerning the philophthalmids. Seasonal periodicity, ecological distribution and dispersal, and migration taxis within the definitive host are possible areas of investigation. Genetic relationships in the genus also deserve prompt attention. With the belief that future work will ensue in descriptive and experimental parasitology with Philophthalmus megalurus, a few suggestions for improved procedures have been discussed. 
Alicata, Joseph E. 1962. Life cycle and developmental stages of Philophthalmus gralli in the intermediate and final hosts. J. Parasitol. 48:47-54.

----, and H. L. Ching. 1960. On the infection of birds and mammals with the cercariae and metacercariae of the eye-fluke, Philophthalmus. J. Parasitol. 46 (Suppl.):16. Abst.

----, and K. Noda. 1960. Observations on the life history of Philophthalmus, a species of eye fluke of birds in Hawaii. IN Libro Homenaje al Dr. Eduardo Caballero y Caballero, 67-73.

Baugh, S. C. 1962. Contributions to our knowledge of digenetic trematodes. V. On two new species of Philophthalmus Looss 1899, and a discussion on the family Philophthalmidae. J. Helminth. 36:243-258.

Belapolskaya, M. M. 1963. (Helminth fauna of Charadriiformes in the Amur area during migration and nesting. I. Trematoda.) Trudy gel'mint. Lab. 13:164-195.

Boyd, Eliz. M. and Anne E. Fry. 1971. Metazoan parasites of the eastern belted kingfisher (Megaceryle alcyon alcyon). J. Parasitol. 57:150-156.

Cable, Raymond, M. 1937. The resistance of the herring gull, Larus argentatus, to experimental infections of the trematode, Parorchis acanthus. J. Parasitol. 23:559.

-.---, and K. L. Hayes. 1963. North American and Hawaiian freshwater species of the genus Philophthalmus (Trematoda:Digenea). J . Parasitol. $49(5$, sect. 2):41. Abst.

Cheng, Th. C. and A. S. Thakur. 1967. Thermal activation and inactivation of Philophthalmus gralli metacercaria. J. Parasitol. 53: 212 .

Ching, H. L. 1961. The development and morphological variations of Philophthalmus gralli Mathis \& Leger 1910, with a comparison of species of Philophthalmus Looss 1899. Proc. Helminth. Soc. Wash. $28: 130-138$.

Dissanaike, A. S. and D. P. Bilimoria. 1958. On an infection of a human eye with Philophthalmus sp. in Ceylon. J. Helminth. $32(3): 115-118$.

Fisher, F. M. and A. Fred West. 1958. Cercaria megalura Cort, 1914, the larva of a species of Philophthalmus. J. Parasitol. $44: 648$. 
Fried, Bernard. 1963. Reinfection of chicks with the ocular trematode Philophthalmus hegeneri Penner \& Fried, 1963. J. Parasitol. 49: 981-982.

----, and John E. Berry. 1961. The use of Equi-Thesin as an anesthetic in avian helminth transplant studies. J. Parasitol. 47:660.

----, and L. R. Penner. 1963. Exposure of chicks to metacercaria of Philophthalmus hegeneri Penner \& Fried, 1963. J. Parasitol. 49: 987-980.

Gower, Carl. 1939. Host-parasite catalogue of the helminths of ducks. Amer. Midl. Nat. $22: 580-628$.

Howell, M. 1965. Notes on a potential trematode parasite of man in New Zealand. Tuatara 13:182-184.

Iskova, N. I. 1967. (Philophthalmus stugii, n. sp. (Trematoidea: Philophthalmidae) from Fulica atra L.). Dopov. Akad. Nauk ukr. RSR Ser B, No. 2:164-166.

$\underline{x}$

Karyakarte, P. P. 1967a. Philophthalmus (Mixophthalmus) chrysommae subgenus et sp. nov. from the orbital cavity of the yellow-eyed babbler, Chrysoma sinensis. Indian J. Helminth. Yr. 1966. 18 (Supp1.) : 25-28.

---, 1967b. Philophthalmus sp. (Trematoda:Philophthalmidae) from the eye of a vilture in India (Corresp.). Curr. Sci. 36:381.

--- , 1968. A new species of Philophthalmus (Trematoda:Philophthalmidae) from the orbital cavity of the pigeon, Columbia livia (Gmelin) in India. Riv. Parassit. 29:253-256.

Khalil, Galila M. and R. M. Cable. 1968. Germinal development in Philophthalmus megalurus (Cort, 1914) (Trematoda:Digenea). Parasitenk. $31: 211-231$.

Krygier, Bruce B. and Ralph w. Macy. 1969. The eye fluke Philophthalmus megalurus (Cort) (Trematoda:Philophthalmidae) in the dipper, Cinclus mexicanus, in Oregon. J. Parasitol. 55:78.

Mathis, C. and M. Leger. 1910. Douve oculair de la poule. Bull. Soc. Pathol. Exot. 3:245-251.

Murty, A. S. 1966. Experimental demonstration of the life cycle of Philophthalmus sp. (Trematoda:Philophthalmidae). Curr. Sci. 35: 366-367.

Oshmarin, P. G. 1963. (Helminths of mammals and birds in the Primorsk region). Moscow: Izdatelstvo Akad. Nauk. SSSR. 322 p.

-n--, and A. M. Parukhin, 1963. (Trematodes and nematodes of birds and 
ADDITIONAL REFERENCES

Bang, B. G. and F. B. Bang. 1958. A comparative study of the vertebrate nasal chamber in relation to upper respiratory infections. Bull. John Hopkins Hosp. 104:107-149.

Cable, R. M. 1965. "Thereby hangs a tail." J. Parasitol. 51:3-12.

Cheng, T. C. and Herbert W. F. Yee. 1968. Histochemical demonstration of aminopeptidase activity associated with the intramolluscan stages of Philophthalmus gralli Mathis \& Leger. Parasitology 58: 473-480.

Fried, B. and L. R. Penner. 1961. Studies on ocular trematodiasis. I. Marine acquired philophthalmiasis. J. Parasitol. $47(4$, sect 2):31.

Isseroff, Hadar. 1964. Fine structure of the eyespot in the miracidium of Philophthalmus megalurus (Cort, 1914). J. Parasitol. 50:549-554.

LaRue, Geo. R. 1957. The classification of digenetic trematodes: a review and a new system. Exp. Parasitol. 6:306-349.

Nollen, P. M. 1968. Autoradiographic studies on reproduction in Philophthalmus megalurus (Cort, 1914) (Trematoda). J. Parasitol. 54:43-48.

Vasilev, I. and I. Denev. 1963. (The life cycle of Philophthalmus sp. in Anser anser domesticus in Bulgaria. I.) Izv. tsent. khelmint. Lab., Sofia, $8: 21-30$.

West, A. F., Jr, and F. M. Fisher, Jr. 1959. The life history of a species of Philophthalmus (Trematoda:Philophthalmidae) from the orbit of birds. J. Parasitol. $45(4$, sect. 2):60. 
mammals of the Sikhote-Alinsk Preserve,) Trudi Sikhote-Alinskogo Gosudastvennogo Zapovednika. 3:121-181.

Penner, Lawrence R. and B. Fried. 1963. Philophthalmus hegeneri sp.n. Ocular trematode from birds. J. Parasitol. 49:974-977.

Thakur, Amar S. and T. C. Cheng. 1968. The formation, structure, and histochemistry of the metacercarial cyst of Philophthalmus gralli Mathis and Leger. Parasitology 58:605-618.

Vasilev, I. and I. Denev. 1965. Research into the life history of Philophthalmus sp., recovered from geese in Bulgaria. I. Ztschr. Parasitenk. Berlin 25:320-329.

West, A. Fred. 1961. Studies on the biology of Philophthalmus gralli Mathis \& Leger, 1910. Amer. Midl. Nat. 66:363-383. 